recession alone is of very little advantage. The best method of procedure is an advancement accompanied by, or without, a recession; but even if the eyes are straight for some months after operation, the squint tends to relapse later.

All patients must learn to co-operate, and they must also learn that the faculty of binocular vision can only be achieved by thinking constantly of using the two eyes together, not only during the time of orthoptic training, but during every waking moment of their normal life.

I would like to thank Mr. Juler and Mr. Williamson-Noble for all their kindnesses to me in the past, and for lending me so many of their beds for my operation cases of squint.

I should also like to mention the fact that the "diplopia goggles" were made for me by Messrs. George Spiller, at a price which is well within. reach of all hospital patients.

\title{
EXTRA-OCULAR INFLUENCE IN GLAUCOMA* (constitutional factors)
}

BY

FARID MASSOUD

CAIRO

IN quoting the words of three different observers, the present-day opinion with regard to glaucoma and extra-ocular influence is best understood.

Wegner' describes glaucoma as " an affection that comes not only from the eyes but also from other extensive localities in the organism."

Jameson Evans ${ }^{2}$ considers glaucoma " as but the ocular symptom complex of a generalised change." While Terson ${ }^{3}$ recommends a glaucomatous patient to be treated as any patient internally diseased.

In point of fact, in the study of glaucoma, the importance must be emphasised of the study of the general body processes going on at the same time in the whole organism. This is not only because of the definite departure from the normal found in certain parts of the body, but also because of the intimate relation that connects them to the local processes going on in the eye.

\footnotetext{
* Read at the Annual Meeting of the Ophthalmological Society of Egypt, March 26, 1937.
} 
In glaucoma certain pathological changes can be demonstrated in the circulatory, nervous and endocrine systems, which changes possibly appearing on first impression as insignificant, unrelated the one to the other, or even contradictory in some cases, are in reality the connected parts of a continuous chain of events having cne source of origin and having one clear significance which further research will make clearer.

In the circulatory system the following changes have been observed :-

(1) Changes in the blood.-Certain elements in the blood are reported to be relatively diminished, e.g., the calcium contentBiffis ${ }^{4}$; others seem to be increased, e.g., the potassium content thus bringing about an increase in the alkaline reserve-Trematore. ${ }^{5}$ The chlorides are also stated to be increased as well as the iodine content-Gionnantoni, ${ }^{6} \mathrm{Passow}^{7}$; on this latter condition, however, some observers mention the reverse.

In the cellular elements of the blood a change occurs in both the red and white blood corpuscles. An increase in the number of the red blood corpuscles has been noted-Passow, while a change in the differential leucocytic blood count also occurs. This change in the leucocytes which consists in a relative increase in the large mononuclears, I have been able to demonstrate since $1929 .^{8}$

In acute cases of glaucoma the large mononuclear leucocytes may attain the remarkable extent of 15 to 20 and even 30 per cent. One noticeable feature in this connection is their apparent independence from any operative relief of intra-ocular tension, their presence seeming to depend not so much on the local condition of the eye as on a general pathological process underlying it, as will be presently explained. Sufficient to refer here to the opinion of Wright ${ }^{9}$, who mentions the probable presence in glaucoma of certain toxins interfering with the function of. the reticulo-endothelial system. (See the list of counts.)

(2) Changes in the capillaries.-Distinct changes have been observed in the structure and function of the vascular and capillary system in glaucoma patients as evidenced by the increased permeability-Meszaros. ${ }^{10}$

In fact the whole peripheral vascular system is altered and the appearance of glaucoma is but its local manifestation-Rossi. ${ }^{11}$ One evidence of this peripheral vascular change is apparent in the curious condition known as "epidemic dropsy" described by Kirwan..$^{12}$

(3) Changes in the blood pressure.-A rise in the average vascular tension has been observed-Rollet, ${ }^{13}$ as well as a rise in the venous pressure-Ciotola. ${ }^{14}$ 


\section{Glaucoma}

Differential Leucocytic Blood Count on cases from The Giza Ophthalmic Hospital during August to December, 1929

\begin{tabular}{|c|c|c|c|c|c|c|c|c|}
\hline Ticket & Age & P. & E. & S.L. & L. L. & L.M.\&T. & Date & History and Remarks \\
\hline 13243 & 55 & $\begin{array}{l}54 \\
40 \\
37 \\
45\end{array}$ & $\begin{array}{l}17 \\
18 \\
20 \\
13\end{array}$ & $\begin{array}{r}9 \\
7 \\
- \\
-\end{array}$ & $\begin{array}{l}15 \\
25 \\
26 \\
35\end{array}$ & $\begin{array}{r}5 \\
10 \\
7 \\
7\end{array}$ & $\begin{aligned} 1.8 .29 \\
27.8 \\
29.8 \\
4.9\end{aligned}$ & L. glauc., R. shrunk trephin. \\
\hline 21031 & 12 & 40 & 20 & 15 & 15 & 10 & 12.10 & Sec. glauc., iridect. 10.10 \\
\hline 19611 & 15 & 45 & 12 & 25 & 10 & 8 & 12.10 & Sec. glauc., iridect. 6.10 \\
\hline 22210 & 70 & $\begin{array}{l}35 \\
54\end{array}$ & $\begin{array}{r}6 \\
10\end{array}$ & $\begin{array}{r}10 \\
8\end{array}$ & $\begin{array}{l}35 \\
20\end{array}$ & $\begin{array}{r}14 \\
8\end{array}$ & $\begin{array}{l}16.11 \\
23.11\end{array}$ & Glauc. trephin. 23.10 \\
\hline 25948 & 40 & $\begin{array}{l}55 \\
50 \\
69 \\
73 \\
70\end{array}$ & $\begin{array}{r}1 \\
4 \\
1 \\
-\end{array}$ & $\begin{array}{r}25 \\
20 \\
10 \\
7 \\
10\end{array}$ & $\begin{array}{r}10 \\
6 \\
10 \\
6 \\
8\end{array}$ & $\begin{array}{r}9 \\
20 \\
10 \\
14 \\
12\end{array}$ & $\begin{array}{r}3.12 \\
8.12 \\
12.12 \\
21.12 \\
26.12\end{array}$ & $\begin{array}{l}\text { Glauc. subacute } 2 \text { months } \\
\text { R.V. p.1, L.V. } 5 / 60 \\
\text { Iridec. L. } 19.12\end{array}$ \\
\hline 26652 & 30 & $\begin{array}{l}60 \\
60 \\
64 \\
55 \\
50 \\
45 \\
52 \\
65\end{array}$ & $\begin{array}{l}4 \\
5 \\
2 \\
3 \\
7 \\
3 \\
5 \\
3\end{array}$ & $\begin{array}{l}14 \\
13 \\
24 \\
15 \\
15 \\
35 \\
16 \\
17\end{array}$ & $\begin{array}{r}16 \\
13 \\
6 \\
15 \\
20 \\
7 \\
16 \\
10\end{array}$ & $\begin{array}{r}6 \\
9 \\
4 \\
12 \\
8 \\
10 \\
11 \\
5\end{array}$ & $\begin{array}{l}12.12 \\
22.12 \\
24.12 \\
28.12 \\
31.12 \\
2.1 .30 \\
5.1 \\
9.1\end{array}$ & $\begin{array}{l}\text { Glauc. } 8 \text { months, V. h.m. } \\
\text { Iridec. both } 21.12\end{array}$ \\
\hline 25418 & 25 & $\begin{array}{l}65 \\
65 \\
60 \\
60\end{array}$ & $\begin{array}{r}5 \\
4 \\
5\end{array}$ & $\begin{array}{l}15 \\
10 \\
12 \\
15\end{array}$ & $\begin{array}{r}5 \\
10 \\
3 \\
10\end{array}$ & $\begin{array}{l}10 \\
15 \\
21 \\
10\end{array}$ & $\begin{array}{l}12.12 \\
19.12 \\
21.12 \\
26.12\end{array}$ & $\begin{array}{l}\text { Glauc. } 4 \text { months, V. } 1 / 60 \\
\text { Iridec. } 18.12\end{array}$ \\
\hline 21990 & 60 & $\begin{array}{l}30 \\
32 \\
37 \\
30\end{array}$ & $\begin{array}{r}20 \\
13 \\
5 \\
20\end{array}$ & $\begin{array}{l}34 \\
25 \\
30 \\
35\end{array}$ & $\begin{array}{r}10 \\
20 \\
20 \\
8\end{array}$ & $\begin{array}{r}6 \\
10 \\
8 \\
7\end{array}$ & $\begin{array}{l}22.12 \\
26.12 \\
2.1 .30 \\
5.1\end{array}$ & $\begin{array}{l}\text { Glauc. R.V. } 5 / 60, \text { L. no p.1. } \\
\text { Iridec. and trephin. } 21.12\end{array}$ \\
\hline 25650 & 25 & $\begin{array}{l}57 \\
42\end{array}$ & $\begin{array}{l}7 \\
3\end{array}$ & $\begin{array}{l}20 \\
25\end{array}$ & $\begin{array}{l}10 \\
20\end{array}$ & $\begin{array}{r}6 \\
10\end{array}$ & $\begin{array}{l}22.12 \\
26.12\end{array}$ & $\begin{array}{l}\text { Glauc. R.V. 1/60, L.V. } 50 \mathrm{cms} \text {. } \\
\text { Iridec. L. } 21.12\end{array}$ \\
\hline 26773 & 55 & $\begin{array}{l}45 \\
50 \\
25 \\
38 \\
25 \\
55\end{array}$ & $\begin{array}{l}12 \\
25 \\
25 \\
30 \\
30 \\
17\end{array}$ & $\begin{array}{l}10 \\
10 \\
10 \\
10 \\
20 \\
15\end{array}$ & $\begin{array}{r}8 \\
5 \\
10 \\
7 \\
10 \\
5\end{array}$ & $\begin{array}{r}25 \\
10 \\
30 \\
15 \\
15 \\
8\end{array}$ & $\begin{array}{l}19.12 \\
24.12 \\
28.12 \\
31.12 \\
2.1 .30 \\
5.1\end{array}$ & $\begin{array}{l}\text { Glauc. R.V. h.m., L. } 2 / 60 \\
\text { Under medical treatment } \\
\text { R. trephin.. L. iridec. } 28.12 \\
\text { Eyes quiet }\end{array}$ \\
\hline
\end{tabular}


The nervous changes met with in glaucoma affect the vegetative nervous system, and are connected with vasoneurosis-Weinstein. ${ }^{15}$ To begin with an understanding of the normal nervous mechanism is essential.

Under normal conditions, says Gradle, ${ }^{16}$ intra-ocular pressure is regulated by variations in the size of the vessels of the choroid and ciliary body, these vessels being controlled by the sympathetic. When arterial pressure rises the sympathetic automatically causes a contraction of these vessels in the eyeball to prevent an overfilling.

When a derangement of this regulatory apparatus occurs as, e.g., a temporary relaxation, then an overfilling of the choroidal vessels is liable to follow a raising in the systemic blood pressure produced by such conditions as, e.g., emotions. The sequelae to this overfilling, i.e., the increase in the contents of the eyeball, the pushing forwards of the lens and iris and the blocking of the angle combined with the continued formation of the aqueous give the necessary requisites to states of rise of tension in the eye.

Thus it is generally conceded that at the root of the glaucomatous change there is a derangement of the sympathetic control of the tension of the eye, but the important point to remember is that this derangement is in fact only a part of a general derangement of the whole vegetative system (nervous), which is usually designated as a disturbance in the equilibrium between the sympathetic and parasympathetic-Heimann. ${ }^{17}$

One evidence of the existence of this general derangement in glaucoma is found in the cases reported by Lagrange, ${ }^{18}$ in which he mentions the occurrence of certain visceral pains, uterine and gastro-intestinal in conjunction with a raised tension in the eyes.

Experimentally also, a rise of tension is known to occur in sympathetic irritation-Bistis. ${ }^{19}$

The changes in the endocrine system include a disturbance in the secretion of the thyroid as well as the basal metabolic ratePassow, Siegert. ${ }^{20}$

A change in the adrenalin also takes place. An upsetting of metabolism is considered by some authors-Duke-Elder ${ }^{21}$ as the origin of the special toxins that influence the uvea and cause the acute crisis or rise of tension.

Very much related to this endocrine factor is the influence of emotions already referred to, which make women more prone to attacks of glaucoma than men-Nelander..$^{22}$

Also of interest to note in this connection is the recent report about folliculin as being markedly increased in the urine in correspondence with the increase in the tension of the eye-Dollfus and Seguy. ${ }^{23}$ 
Significance of these changes.-Coming to analyse these findings one cannot fail to see their clear indication of the presence of a toxin or toxins in the body in cases of glaucoma.

The toxins present in the system constitute the source of origin of all these different changes; their effect on the blood causing its altered condition of diminished calcium, etc.; their effect on the blood-forming tissues producing new cellular formation of large mononuclears, etc.; their effect on the endothelial lining of the capillaries causing the increased permeability, and lastly their effect on the sympathetic and endocrine systems producing the different states of derangement.

Following their natural course of producing vicious circles, these metabolic toxins produce a stimulation in the first stages of their action, followed usually by states of exhaustion through overstimulation, hence the apparent contradiction of observations on such changes as the iodine content or the basal metabolic rate, etc.

The derangement of the sympathetic control of intra-ocular tension is brought about as an accompanying event of this condition of general toxaemia, hence the different manifestations of raised intra-ocular tension.

Practical application.-A clear understanding of extra-ocular influences in glaucoma gives a clear indication of the line of treatment to be followed.

Treatment of the general body toxaemia by elimination should receive the first attention, hence the importance of rest in bed, restricted diet, free intestinal action, diaphoresis and free action of the kidneys-Magitot. ${ }^{24}$

The good results obtained by intravenous injections of such medicines as hypertonic salt solutions or concentrated glucose solutions or others-Gallois and Viard ${ }^{25}$ - can be understood as well as the occasional benefit of such drugs as adrenaline or ergotine-Abadie. ${ }^{26}$

Irradiation of the body has been used with rays acting on the vegetative nervous system (Limited rays of Bucky)-Krasso. ${ }^{27}$

Irradiation has been also used for the thyroid with an improvement of vision and visual field.

Insulin was also made use of to produce a fall in tensionBellavia. ${ }^{28}$

The increase in the large mononuclear cells of the blood might be made use of as one of the early signs which, in conjuction with others, helps in the diagnosis of suspected glaucoma.

In conclusion, one cannot help being impressed by the optimistic opinion of many observers, who mention the future possibility of preventing and even treating conditions of primary glaucoma in their earlier stages on dietetic and general lines with advance of biochemistry and bacteriology. 


\section{REFERENCES}

Wegner.-Ann. d'Ocul., Vol. CLXIX, p. 488, 1932.

Jameson Evans.-Trans. Ophthal. Soc. U.K.. Vol. LIV, p 530, 1934.

Terson.-Ann. d'Ocul., Vol. CLXIX, p. 834, 1932.

Biffis.-Brit. Jl. of Ophthal., Vol. XVIII, p. 116, 1934.

Trematore.-Brit. Jl. of Ophthal., Vol. XVIII, p. 612, 1934.

Gionnantoni.-Brit. Jl. of Ophthal., Vol. XVIII, p. 298, 1934.

Passow.-Ann. d'Ocul.. Vol. CLXIX, p. 483, 1932.

Bull. Ophthal. Soc. of Egypt, Vol. XXIII, p. 38, 1930.

Wright.-Trans. Ophthal. Soc. U.K., Vol. LV, p. 341, 1935.

Meszaros.-Arch. f. Ophthal., p. 331, 1934.

Rossi.-Brit. Jl. of Ophthal., Vol. XVII, p. 53, 1933.

Kirwan.-Brit. Jl. of Ophthal., Vol. XIX, p. 219, 1935.

Rollet.-Soc. franc. d'Ophtal., Vol. XLIV, p. 551, 1931.

Ciotola.-Brit. Jl. of Ophthal., Vol. XX, p. 591, 1936.

Weinstein.-Arch. of Ophthal., Vol XIII, p. 181, 1935. Saunders.

Gradle:-Diseases of the Eye. Conrad Berens, p. 700, 1936.

Heimann.-Ann. d'Ocul., Vol. CLXX, p. 811, 1933.

Lagrange.-Arch. d'ophtal., Vol. XLIX, p. 741, 1932.

Bistis.-Ann. d'Ocul., Vol. CLXIX, p. 150, 1932.

20. Siegert -Zeitschr. f: Augenheilk., Vol. LXXXIX, p. 13, 1936.

21. Duke-Elder.-Brit. Jl. of Ophthal., Vol. XVIII, p. 422, 1934.

22. Nelander.-Brit. Jl. of Ophthal., Vol. XIX, p. 221, 1935.

23. Dollfus and Seguy.-S. O. P., Avril, p. 299, 1936.

24. Magitot.-La Clin. Ophtal., No. 1, 1935.

25. Gallois and Viard.-Soc. franc. d'Ophtal., Vol. XLVIII, p. 439, 1935.

26 Abadie.-Monde Medicale, Mars, 1931.

27. Krasso.-Ann. d'Ocul., Vol. CLXIX, p. 659, 1932 ; Vol. CLXXII, p. 93, 1935.

28. Bellavia.-Brit. Jl. of Ophthal., Vol. XVIII, p. 298, 1934.

\section{ANNOTATION}

\section{"Mors ultima linea rerum est"}

In spite of Horace's dictum which we take as our title there have been many instances in history in which the dead have served the living. In more primitive times the manner in which this was achieved was often crude, for instance, in military engagements the dead were sometimes made to serve as decoys or used as protection for the hard pressed defenders.

In one of Caesar's Gallic wars a barbarian leader hemmed in by a besieging Roman army and hard put to it for food supplies appealed to the aged to sacrifice their lives for the ideal of nourishing those who were young and had to resist the enemy, and even in Napoleon's retreat from Moscow the dead served in a nutritional rôle.

With the march of science other means of utilizing the material of the dead for the needs of the living have been elaborated. In the Great War 1914-1918 there were rumours that human corpses were being utilized for the extraction of animal fats. To-day there is in Moscow a well organized blood transfusion service which utilizes the blood of cadavers to supply the living. To Professor 